Irena Galińska-Rączy

\title{
Ocena możliwości łączenia mandatu posła z funkcją dyrektora SP ZOZ Sanatorium Uzdrowiskowego MSWiA ${ }^{1}$
}

\author{
Assessment of the possibility of combining the mandate of a Deputy \\ with the function of a director of the SP ZOZ Sanatorium of the Ministry \\ of the Internal Affairs and Administration
}

\begin{abstract}
The author of the opinion states that in order to avoid the consequences of violating the substantive incompatibility of a Deputy's mandate, it is advisable to take an unpaid leave by the director of the Health Resort Sanatorium of the Ministry of Internal Affairs and Administration, as he manages an entity being a state legal person conducting a business activity with the use of state property, what is contrary to the provisions of the Act on the Exercise of the Mandate of a Deputy or Senator.
\end{abstract}

Keywords: director, Deputy, mandate

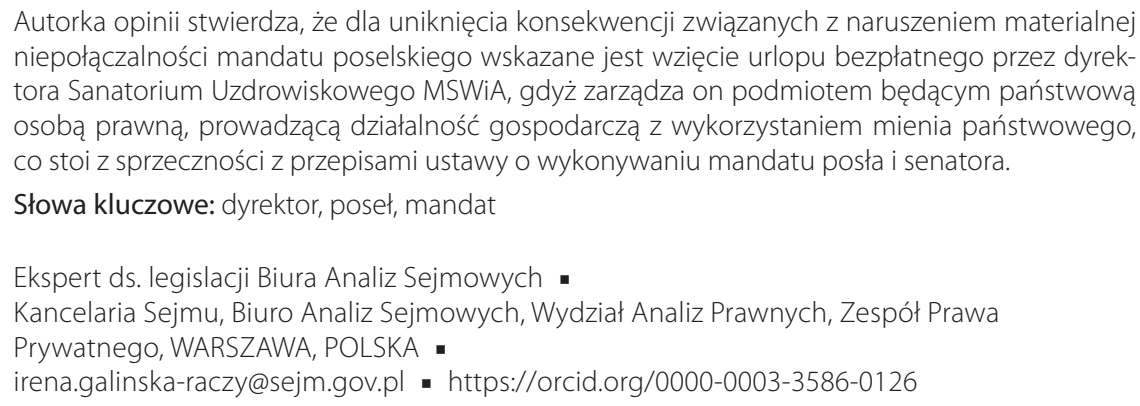

Autorka opinii stwierdza, że dla uniknięcia konsekwencji związanych z naruszeniem materialnej niepołączalności mandatu poselskiego wskazane jest wzięcie urlopu bezpłatnego przez dyrektora Sanatorium Uzdrowiskowego MSWiA, gdyż zarządza on podmiotem będącym państwową osobą prawną, prowadzącą działalność gospodarczą z wykorzystaniem mienia państwowego, co stoi z sprzeczności z przepisami ustawy o wykonywaniu mandatu posła i senatora.

Słowa kluczowe: dyrektor, poseł, mandat

Ekspert ds. legislacji Biura Analiz Sejmowych •

Kancelaria Sejmu, Biuro Analiz Sejmowych, Wydział Analiz Prawnych, Zespół Prawa

Prywatnego, WARSZAWA, POLSKA -

irena.galinska-raczy@sejm.gov.pl • https://orcid.org/0000-0003-3586-0126

\section{Przedmiot opinii}

Przedmiotem niniejszej opinii prawnej jest odpowiedź na następujące pytanie: „czy mogę łączyć mandat posła ze sprawowaniem funkcji dyrektora SP ZOZ Sanatorium Uzdrowiskowego MSWiA w Wraz z pytaniem, w celu uzyskania opinii co do konkretnego stanu faktycznego, przedstawiono: statut tego podmiotu, wydruk z KRS oraz kopię aktu notarialnego z 1 października 2019 r., na podstawie którego doszło do przeniesienia włas-

1 Opinia prawna $w$ sprawie możliwości łączenia mandatu poselskiego $z$ funkcja dyrektora SP ZOZ Sanatorium Uzdrowiskowego MSWiA w sporządzona 29 października 2019 r. na zlecenie dyrektora Biura Analiz Sejmowych; BAS-WAP 2000/19. 
ności dwóch nieruchomości Skarbu Państwa (pozostających w odpłatnym zarządzie Ministerstwa Spraw Wewnętrznych) na rzecz Sanatorium jako państwowej osoby prawnej (na podstawie art. 51 ust. 2 ustawy z 21 sierpnia 1997 r. o gospodarce nieruchomościami, Dz.U. 2018, poz. 2204, ze zm.). Poseł elekt wyraził zamiar łączenia funkcji dyrektora tej jednostki z mandatem posła „w formule niezawodowej", czyli sprawowania mandatu bez korzystania z tzw. poselskiego urlopu bezpłatnego.

Odnosząc się do powyższej wątpliwości, należy przeanalizować status prawny SP ZOZ Sanatorium Uzdrowiskowego MSWiA w

oraz dyrektora tej jednostki, mając na względzie zakaz bezwzględnej niepołączalności formalnej (art. 103 ust. 1 Konstytucji) oraz niepołączalności materialnej (wynikający z art. 34 ustawy z 9 maja 1996 r. o wykonywaniu mandatu posła i senatora; dalej: u.w.m.p.s.).

\section{Status prawny SP ZOZ Sanatorium Uzdrowiskowego MSWiA}

Samodzielny Publiczny Zakład Opieki Zdrowotnej Sanatorium Uzdrowiskowe MSWiA w , dalej: Sanatorium lub Sanatorium MSWiA, jest podmiotem leczniczym niebędącym przedsiębiorcą, o którym mowa w art. 2 ust. 1 pkt $4 \mathrm{w}$ związku z art. 4 ust. 1 pkt 2 ustawy z 15 kwietnia 2011 r. o działalności leczniczej (Dz.U. 2018, poz. 2190, ze zm.).

Podmiot ten został utworzony przez ministra właściwego do spraw wewnętrznych i wyposażony w osobowość prawną (zarządzenie nr 11 Ministra Spraw Wewnętrznych i Administracji z 23 marca 2017 r. w sprawie nadania statutu Samodzielnemu Publicznemu Zakładowi Opieki Zdrowotnej Sanatorium Uzdrowiskowemu Ministerstwa Spraw Wewnętrznych i Administracji w

(Dz.Urz. MSWiA 2017, poz. 11, zm.

Dz.Urz. MSWiA 2018, poz. 35).

Sanatorium należy do jednostek nadzorowanych przez Ministra Spraw Wewnętrznych i Administracji [podmiot ten został wymieniony w zał. nr II do obwieszczenia Ministra Spraw Wewnętrznych i Administracji z 27 września 2018 r. w sprawie wykazu jednostek organizacyjnych podległych Ministrowi Spraw Wewnętrznych i Administracji lub przez niego nadzorowanych; M.P. 2018, poz. 965].

\section{Niepołączalność formalna}

1. Artykuł 103 ust. 1 Konstytucji stanowi, że mandatu posła nie można łączyć m.in. $\mathrm{z}$ zatrudnieniem $\mathrm{w}$ administracji rządowej oraz że zakaz ten nie dotyczy członków Rady Ministrów i sekretarzy stanu w administracji rządowej. Konsty- 
tucyjne pojęcie „administracja rządowa” budzi znaczne wątpliwości interpretacyjne. W związku z tymi wątpliwościami Biuro Analiz Sejmowych sporządziło opracowanie pt. Zasady oceny sytuacji prawnej posła $w$ związku z niepołaczalnościa jego mandatu ${ }^{2}$. W Zasadach wskazano dwa kluczowe kryteria oceny, które muszą być spełnione jednocześnie, aby uznać, że dany podmiot należy do administracji rządowej. W opracowaniu tym stwierdzono: administracja rzadowa to podmioty, które podlegaja kierownictwu Rady Ministrów w rozumieniu art. 146 ust. 3 Konstytucji (należy przez to rozumieć ich zależność osobowa lub zależność służbowa względem Rady Ministrów) oraz nie maja osobowości prawnej.

Pierwsze z kryteriów, tj. podległość Radzie Ministrów, wynika wprost z przepisów Konstytucji (art. 146 ust. 3). Drugie zaś powstało w wyniku następującej interpretacji ustawy zasadniczej: [n] a gruncie regulacji konstytucyjnej wyposażenie podmiotu administrującego w taką osobowość (przyznanie mu prawa do dysponowania - we własnym imieniu i na własny rachunek - odrębnym od Skarbu Państwa majatkiem, czyli prawami podmiotowymi o charakterze prywatnoprawnym), stanowi wyraz samodzielności tego podmiotu względem pozostałej części aparatu administracyjnego państwa (por. art. 165 Konstytucji). Taka gwarantowana prawnie i chroniona sadownie samodzielność jest uznawana z kolei za przejaw decentralizacji administracji publicznej, a zatem uchylenia hierarchicznej więzi, która określa relacje między podmiotami znajdujacymi się $w$ ramach tej samej struktury administracyjnej. Przyjmując te założenia, należy uznać, że podmioty administrujące - które mają osobowość prawną odrębna względem osobowości prawnej Skarbu Państwa lub też osobowości prawnej gminy, powiatu, samorządu województwa dysponuja ustawowymi gwarancjami samodzielności względem odpowiednio: administracji rzadowej albo administracji samorzadu terytorialnego, iz tego powodu nie moga zostać uznane za części składowe ich struktury organizacyjnej.

Przyjęte kryterium osobowości prawnej może budzić wątpliwości interpretacyjne ${ }^{4}$, jednakże prezentowane od 2011 r. stanowisko Biura Analiz Sejmowych

\footnotetext{
„Zeszyty Prawnicze” 2011, nr 3(31).

Ibidem, s. 204, 205.
}

4 Wątpliwości te były podnoszone m.in. przez J. Jagielskiego w ekspertyzie Łączenie mandatu posła $z$ wykonywaniem pracy nauczyciela $w$ samorzadowej szkole podstawowej, opublikowanej w zbiorze Status posła w opiniach Biura Analiz Sejmowych (20072015), t. II, cz. 2, red. I. Galińska-Rączy, Warszawa 2015. Według J. Jagielskiego: Osobowość prawna stanowi cechę (przymiot) podmiotu, skutkujacca przede wszystkim w sferze prywatnoprawnej (cywilnoprawnej), a nie na płaszczyźnie publicznoprawnej. Wyraża ona samodzielność tego podmiotu w pierwszym rzędzie w stosunkach cywilnoprawnych, a nie w zakresie samodzielności w sferze prawa publicznego (administracyjnego), która mierzona jest kwota praw i obowiązków oraz zadań $i$ kompetencji o charakterze prawnoadministracyjnym. Choć oczywiście osobowość prawna w jakimś stopniu utwierdza też samodzielność i podmiotowość prawnoadministracyjna (jak np. w przypadku jednostek samorzadu terytorialnego, tj. gminy, powiatu czy województwa). Wśród pod- 
(opracowane w omawianych Zasadach) w zakresie osobowości prawnej jako negatywnej przesłanki warunkującej stosowanie art. 103 ust. 1 ustawy zasadniczej zostało podtrzymane w referacie Prawne ograniczenia publicznej, zawodowej i gospodarczej działalności posłów ${ }^{5}$. W związku z tym wyposażenie jakiegoś podmiotu w osobowość prawną, zdaniem Biura Analiz Sejmowych, uniemożliwia stosowanie zakazu wynikającego z art. 103 ust. 1 Konstytucji RP.

2. Pierwszym zagadnieniem, jakie należy rozważyć, jest stwierdzenie, czy podmiot leczniczy może być uznany za podmiot pozostający w systemie administracji. Dopiero po odpowiedzi pozytywnej, należy rozważyć, czy jest to administracja rządowa, o której mowa w art. 103 Konstytucji RP.

W opinii M. Szydło pojęcie „administracja” występujące w art. 103 ust. 1 zdanie pierwsze Konstytucji RP powinno być6: pojmowane $w$ znaczeniu podmiotowo-przedmiotowym i obejmować te podmioty (organy, struktury, jednostki organizacyjne), które zostały powołane do życia przez ustawodawce $w$ tym celu, aby wykonywać administracje publiczna $w$ znaczeniu przedmiotowym, w tym takize (a niekiedy nawet wyłacznie) $w$ formach niewładczych ${ }^{7}$. Autor ten zalicza do pod-

miotów administrujących, a więc tych, które składają się na administrację w interesującym nas organizacyjnym ustrojowym sensie sa podmioty nie posiadające ze swej istoty osobowości prawnej, jak organy administracyjne czy urzędy administracyjne (zarówno administracji rządowej, jak i samorządowej), a także podmioty wyposażone $w$ tę osobowość, a których przynależność do kategorii administracji nie budzi na ogół wątpliwości, jak m.in. zakłady administracyjne czy agencje rządowe (te ostatnie przynależa do administracji rzadowej). Ekspertyza ta została powołana w opinii I. Galińskiej-Rączy Czy podjęcie pracy na stanowisku dyrektora ośrodka kultury (samorządowej instytucji kultury) nie będzie kolidować z petnieniem mandatu posła (opinia publikowana w tym zbiorze).

Podobne stanowisko w tej kwestii zajmuje m.in. M. Stahl w odniesieniu do kategorii „podmioty administrujące” [w:] System prawa administracyjnego, t. 6, Podmioty administrujące, red. R. Hauser, Warszawa 2011, s. 18-23, która powołuje np. J. Zimmermanna (autor ten zalicza do podmiotów administrujących m.in. „kierowników państwowych osób prawnych” oraz agencje rządowe), P. Radziewicz, Decentralizacja jako pojeccie prawne, „Kwartalnik Prawa Publicznego” 2005, nr 1-2, oraz M. Szydło, Zakaz łączenia mandatu parlamentarnego. Studium prawne, Warszawa 2012, s. 87-88.

5 Z. Cieślik, Prawne ograniczenia publicznej, zawodowej i gospodarczej działalności posłów [w:] Seminarium dla nowo wybranych posłów IX kadencji, Warszawa 2019.

${ }^{6}$ Autor wskazuje wyrok Trybunału Konstytucyjnego z 28 czerwca 2000 r. w sprawie o sygn. akt K 25/99, w którym Trybunał, powołując się na doktrynę prawa administracyjnego, stwierdził: [...] $w$ doktrynie prawa administracyjnego pod pojęciem „administracji publicznej” rozumie się przejęte przez państwo i realizowane przez jego zawisłe organy, a także przez organy samorzadu terytorialnego, zaspokajanie zbiorowych $i$ indywidualnych potrzeb obywateli, wynikajacych ze wspólżycia ludzi w społecznościach, M. Miemiec [w:] Prawo administracyjne, red. J. Boć, Wrocław 1997, s. 14.

7 M. Szydło, Zakaz łączenia, op. cit., s. 87. 
miotów administracji publicznej (administracji rządowej i samorządu terytorialnego) rozmaite zakłady administracyjne, a więc samodzielne podmioty, które zostały powołane do wykonywania zadań publicznych (najczęściej w sferze tzw. administracji świadczącej), którym przydzielono zespół środków osobowych oraz rzeczowych, a wśród nich wymienia: szkoły, instytucje kultury i podmioty lecznicze ${ }^{8}$. Zakłady publiczne (administracyjne), będac powoływane zawsze do wykonywania pewnych zadań z zakresu przedmiotowo pojmowanej administracji (chociażby w ochronie zdrowia, oświaty i kultury), należa do niejako klasycznych elementów administracji publicznej, stanowiąc nieodzowny składnik tejże administracji ${ }^{9}$.

Dla rozważanej kwestii istotny wydaje się pogląd prezentowany w doktrynie na temat podmiotów administracji świadczącej (do których należą m.in. samodzielne publiczne zakłady opieki zdrowotnej; dalej: sp zoz)): Zakład opieki zdrowotnej jest wyodrębnionym organizacyjnie zespołem osób i środków majątkowych utworzonym i utrzymywanym w celu udzielania świadczeń ochrony zdrowia. Podstawe jego działania stanowi art. 68 Konstytucji RP. Przepis ten ma podwójny charakter. Z jednej strony, normuje prawa podmiotowe określonych osób do ochrony zdrowia, przyjmując, że użytkownikiem zakładów opieki zdrowotnej może być każdy człowiek. Z drugiej strony, ten przepis wskazuje obowiazek działania władz publicznych w zakresie ochrony zdrowia. Nakaz taki czyni ochronę zdrowia funkcja publiczna. Konsekwencja takiego stanu prawnego jest przyznanie zakładowi opieki zdrowotnej przymiotu zakładu publicznego ze względu na funkcje publiczna, jaka jest ochrona zdrowia.

W takim ujęciu, o publicznym charakterze zakładów opieki zdrowotnej nie decyduje publiczny charakter podmiotów, które je tworza, ale rodzaj świadczonych usług. Zakład opieki zdrowotnej może być utworzony zarówno przez podmioty publiczne (np. minister, jednostka samorzadu terytorialnego), jak i niepubliczne (np. pracodawca, spółka niemająca osobowości prawnej, osoba fizyczna). Moga to być zarówno podmioty wyposażone w osobowość prawna (np. jednostka samorzadu terytorialnego, stowarzyszenie, inne osoby prawne), jak i podmioty wyposażone jedynie w podmiotowość administracyjnoprawna (np. minister, wojewoda).

Publiczny charakter zakładów opieki zdrowotnej wymaga poddania ich władztwu administracji publicznej, odpowiedzialnej za prawidłowa realizacje ochrony $z$ drowia. W pierwszej kolejności przejawia się to $w$ reglamentacji procedury tworzenia i likwidacji zakładów opieki zdrowotnej ${ }^{10}$.

Ibidem, s. 156.

$9 \quad$ M. Szydło zalicza np. do administracji samorządu terytorialnego zakłady publiczne (administracyjne), takie jak podmioty utworze i prowadzone przez jednostki samorządu terytorialnego, w tym również podmioty lecznicze działające w formie spółki kapitałowej, ibidem, s. 157.

10 Z. Czarnik, J. Posłuszny [w:] System prawa administracyjnego, t. 6, Podmioty administrujące, red. R. Hauser, Warszawa 2011, s. 460-461. 
3. J. Jagielski, analizując pojęcie "administracja samorządu terytorialnego" (wynikające $\mathrm{z}$ art. 30 u.w.m.p.s.), przyjmuje, że: [...] na gruncie doktrynalnym podmioty majace status np. zakładów administracyjnych (np. szkoła, przedszkole, zakład opieki zdrowotnej itp.) traktowane sa jako podmioty administrujace na równi $z$ organami $i$ urzędami administracyjnymi $z$ kolei zaś np. przedsiębiorstwa komunalne czy inne podmioty włączane sa także do tejże kategorii podmiotów administrujacych, o ile wyposażone sa w funkcje i zadania ze sfery administracji (pojmowanej przedmiotowo), przy czym to właczenie określane jest zwykle miarami funkcji zleconych administracji. Niewatpliwie więc „samorządowe jednostki organizacyjne" maja przynajmniej w części właściwości podmiotów administrujących ${ }^{11}$. Pogląd ten należy odnieść również do sp zoz-ów, dla których organem założycielskim jest organ administracji rządowej - a tak jest w wypadku przedmiotowego Sanatorium MSWiA.

Sanatorium można zaliczać do jednostek administracji wykonujących funkcję administracji niewładczo-świadczącej, czyli administracji będącej wytwórca usług $i$ świadczeń $w$ sferze zaspokajania potrzeb powstających $w$ wielkich zbiorowościach ludzkich ${ }^{12}$.

$\mathrm{W}$ odniesieniu do administracji samorządu terytorialnego $\mathrm{w}$ literaturze zwraca się uwagę na fakt, że zmieniła się ogólna formuła kompetencyjna (zadaniowa) współczesnego samorządu terytorialnego. Do zadań samorządu należą m.in. sprawy związane z infrastrukturą techniczną (np. drogi, wodociągi, komunikacja publiczna) oraz infrastrukturą społeczną (np. szkoły, ochrona zdrowia, opieka społeczna) $)^{13}$.

W doktrynie uznaje się, że współczesna administracja publiczna składa się z systemu organów oraz innych podmiotów publicznych powołanych do wykonywania zadań $\mathrm{z}$ zakresu tej administracji, przy czym podmioty publiczne tworzą aparat administracyjny ${ }^{14}$. W skład tego aparatu wchodzą: organy administracji publicznej (którymi w przypadku samorządu terytorialnego są organy stanowiące, kontrolne i wykonawcze samorządu terytorialnego), państwowe i sa-

11 J. Jagielski, Łączenie wykonywania mandatu posła, op. cit., s. 398-399.

12 Tak M. Stahl, Pojęcie administracji, jej cechy i funkcje [w:] Prawo administracyjne, pojęcia, instytucje, zasady $w$ teorii i orzecznictwie, red. M. Stahl, Warszawa 2009. Autorka powołując się na literaturę, zwraca uwagę na coraz bardziej znaczącą rolę takiej administracji: Szczególna rolę zaczęła odgrywać funkcja zaspokajania podstawowych potrzeb bytowych ludzi, zwłaszcza $w$ miastach, i organizowania usług $w$ dziedzinie infrastruktury komunalnej, oświaty, kultury, w sferze socjalnej. [...] Administracja, która dotychczas była głównie gwarantka porządku prawnego oraz spokoju i bezpieczeństwa publicznego, stała się głównym organizatorem usług publicznych, zobowiązanym do tworzenia odpowiedniej bazy materialnej i świadczenia tych ustug.

13 Z. Niewiadomski [w:] Prawo administracyjne, red. Z. Niewiadomski, Warszawa 2011.

14 R. Michalska-Badziak, Podmioty administrujące [w:] Prawo administracyjne, pojęcia, instytucje, zasady w teorii i orzecznictwie, red. M. Stahl, Warszawa 2009, s. 251-252. 
morządowe jednostki organizacyjne oraz instytucje publiczne. Wedle omawianego systemu administracji publicznej należą do niej m.in. zakłady publiczne ${ }^{15}$, do których zalicza się np. sp zoz-y. Zakłady publiczne (dawniej zakłady administracyjne) są bowiem definiowane jako podmioty wykonujące zadania administracji publicznej w sferze ochrony zdrowia, pomocy społecznej, oświaty i kultury ${ }^{16}$. Zakłady administracyjne (zakłady publiczne) mogą działać jako osoby prawne (w takiej formie działają np. podmioty lecznicze - sp zoz-y - w tym Sanatorium MSWiA będące szczególnym rodzajem takich podmiotów, oraz instytucje kultury), jednostki budżetowe lub zakłady budżetowe ${ }^{17}$.

Z powyższego wynika, że Sanatorium MSWiA jako sp zoz wykonuje administrację publiczną w znaczeniu przedmiotowym (tj. organizatorską działalność państwa, polegającą na zaspokajaniu potrzeb społeczeństwa w zakresie ochrony zdrowia), wykonując przy tym funkcję ustanowioną konstytucyjnie, jaką jest ochrona zdrowia. W myśl przepisów ustawy o działach administracji rządowej minister właściwy do spraw zdrowia kieruje działem „Zdrowie”, który obejmuje m.in. sprawy ochrony zdrowia i zasad organizacji opieki zdrowotnej, sprawy nadzoru nad produktami leczniczymi i wyrobami medycznymi, sprawy organizacji i nadzoru nad systemem Państwowe Ratownictwo Medyczne oraz sprawy zawodów medycznych (art. 33 ust. 1 ustawy o działach administracji rządowej). Minister kierujący działem „Zdrowie” jest właściwy we wszystkich sprawach z zakresu administracji rządowej określonych przez ustawę o działach administracji rządowej jako mieszczących się w dziale „Zdrowie” (art. 4 ust. 2 ustawy o działach administracji rządowej).

4. Powyższe stanowisko należy uzupełnić, mając na względzie szczególny charakter Sanatorium MSWiA, którego cele i zadania polegają m.in. na organizowaniu i prowadzeniu turnusów w zakresie rehabilitacji leczniczej służb mundurowych, medycznym zabezpieczeniu wykonywanych przez ministra spraw wewnętrznych zadań obronnych, medycznym zabezpieczeniu działań służb podległych ministrowi właściwemu do spraw wewnętrznych oraz wykonywaniu zadań nałożonych przez tego ministra ( $\$ 7$ pkt 3, 7-9 statutu). Z zadań tych wynika, że placówka ta m.in. udziela świadczeń, które wykraczają poza formułę

15 Gospodarka komunalna może być prowadzona w ramach takich form organizacyjnoprawnych, jak np. zakłady administracyjne („komunalne zakłady użyteczności publicznej”), do których zalicza się m.in. instytucje kultury czy ochrony zdrowia, C. Banasiński, M. Kulesza, Ustawa o gospodarce komunalnej. Komentarz, Warszawa 2002, komentarz do art. 2.

16 R. Michalska-Badziak, Podmioty administrujace, op. cit., s. 251-252 oraz 260. A. Wiktorowska [w:] Prawo administracyjne, red. M. Wierzbowski, Warszawa 2011, mówi o jednostkach organizacyjnych powoływanych przez organy administracji do różnego rodzaju zadań z zakresu świadczeń typu opieka społeczna, zdrowotna, oświata.

17 I. Lipowicz [w:] Prawo administracyjne, red. Z. Niewiadomski, Warszawa 2011, s. $208 \mathrm{i} \mathrm{n.}$ 
„zaspokajania zbiorowych i indywidualnych potrzeb obywateli”, ponieważ działa również na rzecz służb, które podlegają ministrowi, oraz że wykonuje ona inne zadania (polecenia) nakładane przez ten organ administracji rządowej.

Zgodnie z ustawą 4 września 1997 r. o działach administracji rządowej (Dz.U. 2019, poz. 945): 1. Dział sprawy wewnętrzne obejmuje m.in. sprawy: 1) ochrony bezpieczeństwa i porządku publicznego; 2) ochrony granicy Państwa, kontroli ruchu granicznego i cudzoziemców oraz koordynacji działań zwiąanych z polityka migracyjna państwa; 3) zarzadzania kryzysowego; 4) obrony cywilnej; 5) ochrony przeciwpożarowej, zaś minister ds. wewnętrznych sprawuje nadzór nad działalnościa Policji, Straży Granicznej, Państwowej Straży Pożarnej, Obrony Cywilnej Kraju, Szefa Urzędu do Spraw Cudzoziemców, Krajowego Centrum Informacji Kryminalnej oraz Stużby Ochrony Państwa ${ }^{18}$.

Nieodzowne jest również powołanie art. 146 ust. 4 pkt 7 Konstytucji, zgodnie z którym: W zakresie i na zasadach określonych $w$ Konstytucji i ustawach Rada Ministrów w szczególności: [...] zapewnia bezpieczeństwo wewnętrzne państwa oraz porzadek publiczny ${ }^{19}$.

Zadania określone w powyższy sposób przez Konstytucję RP, jakie ma realizować Rada Ministrów, a dokładnie m.in. minister właściwy ds. wewnętrznych w ramach wyodrębnionego działu administracji rządowej, wskazują na pozostawanie Sanatorium MSWiA (jako podmiotu utworzonego i nadzorowanego przez tego ministra) $\mathrm{w}$ systemie organizacyjno-funkcjonalnym poddanym kierownictwu Rady Ministrów. Sanatorium działa bowiem w obszarze zadań i spraw, które ustawowo podlegają ministrowi właściwemu ds. zdrowia oraz ministrowi właściwemu ds. wewnętrznych.

5. Badając wypełnienie przesłanki „kierownictwa Rady Ministrów” warunkującej zaliczenie Sanatorium MSWiA do administracji rządowej, należy przywołać argument prawny wskazujący na podległość służbową tego podmiotu ministrowi ds. wewnętrznych, jaka wynika z nadzoru sprawowanego przez tego ministra nad tą placówką z obwieszczenia Ministra Spraw Wewnętrznych i Administracji z 27 września 2018 r. w sprawie wykazu jednostek organizacyjnych podległych Ministrowi Spraw Wewnętrznych i Administracji lub przez niego nadzorowanych.

18 Na podstawie rozporządzenia Prezesa Rady Ministrów z 14 sierpnia 2019 r. w sprawie szczegółowego zakresu działania Ministra Spraw Wewnętrznych i Administracji (Dz.U. poz. 1540) organami podległymi temu ministrowi są m.in.: Komendant Główny Policji, Komendant Główny Straży Granicznej, Komendant Główny Państwowej Straży Pożarnej, Komendant Służby Ochrony Państwa, Szef Obrony Cywilnej Kraju.

19 W komentarzu do tego przepisu D. Dudek [w:] Konstytucja RP, t. II, Komentarz. Art. 87-243, red. M. Safjan, L. Bosek, Warszawa 2016, stwierdza: Zapewnienie ochrony bezpieczeństwa i porządku publicznego stanowi konstytucyjna powinność wielu organów władzy (por. D. Dudek, "Konstytucyjne podstawy ochrony bezpieczeństwa”, s. 44 i n.), jednak niewątpliwie powierzoną w szczególny sposób rządowi. 
We wcześniejszych opiniach BAS nadzór sprawowany przez ministra stanowił przesłankę do uznania zatrudnienia na stanowisku Komendanta Głównego Ochotniczych Hufców Pracy ${ }^{20}$ oraz zatrudnienia w Państwowym Gospodarstwie Leśnym „Lasy Państwowe” jako zatrudnienia w administracji rządowej ${ }^{21}$.

6. Analizując aspekt pozostawania Sanatorium w ramach kierownictwa sprawowanego wobec tego podmiotu przez ministra ds. wewnętrznych (poza nadzorem ustalonym expressis verbis w obwieszczeniu Ministra Spraw Wewnętrznych i Administracji z 27 września 2018 r. w sprawie wykazu jednostek organizacyjnych podległych Ministrowi Spraw Wewnętrznych i Administracji lub przez niego nadzorowanych), należy stwierdzić, że istotne znaczenie ma przy tym fakt, że minister spraw wewnętrznych tworzy ten podmiot, może go również zlikwidować oraz nadaje mu statut.

W Zasadach oceny sytuacji prawnej posła $w$ związku z niepołączalnościa jego mandatu zwrócono uwagę na m.in. na podległość w sensie zależności osobowej (lub służbowej) podmiotów zależnych od kierownictwa rządowego (o którym mowa w art. 146 ust. 3 Konstytucji).

O występowaniu owych zależności (organizacyjnych, funkcjonalnych i personalnych) świadczą następujące postanowienia statutu Sanatorium MSWiA:

- Zastępcy kierownika Sanatorium i główny księgowy moga zostać zatrudnieni po zatwierdzeniu kandydatur przez ministra właściwego do spraw wewnętrznych (\$10 ust. 3),

- Do zadań rady społecznej należy:

1) przedstawianie ministrowi właściwemu do spraw wewnętrznych wniosków i opinii $w$ sprawach:

a) zbycia, oddania $w$ dzierżawę, najem, użytkowanie oraz użyczenie aktywów trwałych Sanatorium,

b) zakupu lub przyjęcia darowizny nowej aparatury i sprzętu medycznego przez Sanatorium,

20 E. Gierach w: Uzupetnienie notatki na temat oceny poprawności formalnej oświadczenia o rezygnacji z funkcji i stanowisk objętych niepołączalnością bezwzględna złożonego przez Posła AS z 6 listopada 2015 r. nr BAS WAUiP 2286(11)/15, niepubl., stwierdziła, że: W myśl art. 11 ust. 1 i 2 ustawy z dnia 20 kwietnia 2004 r. o promocji zatrudnienia i instytucjach rynku pracy (t.j. Dz.U. z 2015 poz. 149 ze zm.) stanowiq one państwowa jednostkę budżetowa, nadzorowana przez ministra właściwego do spraw pracy. W konsekwencji przynależa do sfery centralnej administracji rządowej, co potwierdzit Trybunału Konstytucyjny w wyroku $z$ dnia 25 listopada 2002 r. (sygn. akt K 34/01).

${ }^{21}$ J. Jagielski, Problem zaliczania Państwowego Gospodarstwa Leśnego „Lasy Państwowe” do kategorii „administracja rządowa” [w:] Status posła, cz. II, red. I. Galińska-Rączy, Warszawa 2007, s. 186, uznał nadzór ministra nad PGL „Lasy Państwowe” za pozostawanie $w$ organizacyjnych związkach $z$ organem administracji rządowej (art. 4 ust. 4 ustawy o lasach stanowi, że nadzór nad PGL LP sprawuje minister właściwy do spraw środowiska). 
c) zwiazanych z przekształceniem lub likwidacja, rozszerzeniem lub ograniczeniem działalności Sanatorium,

d) przyznawania kierownikowi nagród;

e) rozwiazania stosunku pracy lub umowy cywilnoprawnej o zarządzanie Sanatorium $z$ kierownikiem $-z$ własnej inicjatywy lub na wniosek ministra właściwego do spraw wewnętrznych (\$14),

- Od uchwaly rady społecznej kierownikowi przysługuje odwołanie do ministra właściwego do spraw wewnętrznych (\$15),

- Spory wynikłe między kierownikiem a rada społeczna rozstrzyga minister właściwy do spraw wewnętrznych ( $\$ 16)$,

- 2. Minister właściwy do spraw wewnętrznych zatwierdza sprawozdanie finansowe.

3. Minister właściwy do spraw wewnętrznych dokonuje wyboru firmy audytorskiej do przeprowadzenia badania sprawozdania finansowego.

4. Minister właściwy do spraw wewnętrznych zatwierdza propozycję kierownika dotyczaca podziału zysku oraz sposobu pokrycia straty (\$19),

- Sanatorium jest obowiązane uzyskać zgodę ministra właściwego do spraw wewnętrznych w szczególności na:

1) zbycie, oddanie $w$ dzierżawę, najem, użytkowanie oraz użyczenie aktywów trwalych Sanatorium;

2) zmiany związane z rozszerzeniem lub ograniczeniem działalności Sanatorium;

3) zaciagnięcie kredytu lub pożyczki przez Sanatorium;

4) zakup lub przyjęcie darowizny nowej aparatury i sprzętu medycznego powyżej jednostkowej wartości poczatkowej wynoszacej $20000 \mathrm{zt;}$

5) nabycie na rzecz Sanatorium aktywów trwałych o jednostkowej wartości przekraczajacej $50000 \mathrm{zl}$;

6) zawieranie umów zlecenia na czas dłuższy niż 12 miesięcy oraz umów zlecenia i umów o dzieło, których wartość przekracza 100000 zł w roku, z wyłączeniem umów w zakresie udzielania świadczeń zdrowotnych;

7) prowadzenie działalności innej niż działalność lecznicza;

8) zmiane wierzyciela Sanatorium (\$21).

Według M. Szydło „kierowanie” w rozumieniu art. 146 ust. 3 Konstytucji RP oznacza sprawowanie przez Radę Ministrów nadzoru hierarchicznego nad danym podmiotem administracji (RM jest organem nadrzędnym a dany podmiot ma status podmiotu podległego $)^{22}$. W opinii tego autora chodzi nie tylko o kierownictwo bezpośrednie $\mathrm{RM}$, ale również o kierownictwo pośrednie sprawowane przez poszczególnych ministrów (a nawet organy lub jednostki podległe lub nadzorowane przez poszczególnych ministrów).

22 M. Szydło, Zakaz łączenia, op. cit., s. 87. 
7. Mimo że Sanatorium MSWiA może być kwalifikowane jako podmiot podlegający kierownictwu Rady Ministrów w rozumieniu art. 146 ust. 3 Konstytucji, ze względu na wyposażenie w osobowość prawną nie spełnia jednej z przesłanek przyjętych przez Biuro Analiz Sejmowych (ustalonych w Zasadach oceny sytuacji prawnej posła $w$ związku z niepołączalnościa jego mandatu ${ }^{23}$ ) umożliwiających stosowanie zakazu z art. 103 ust. 1 Konstytucji RP.

Jak stwierdzono wcześniej, stanowisko zaprezentowane w Zasadach przez Biuro Analiz Sejmowych w zakresie osobowości prawnej jako negatywnej przesłanki warunkującej stosowanie art. 103 ust. 1 ustawy zasadniczej zostało podtrzymane w referacie Prawne ograniczenia publicznej, zawodowej i gospodarczej działalności posłów opublikowanym w zbiorze Seminarium dla nowo wybranych posłów IX kadencji, Wydawnictwo Sejmowe, Warszawa 2019.

\section{Niepołączalność materialna}

1. W $\$ 10$ statutu Sanatorium MSWiA zawarto następujące postanowienie: Kierownik kieruje Sanatorium i reprezentuje Sanatorium na zewnątrz. Postanowienie to oznacza, że dyrektor tej placówki m.in. kieruje (zarządza) działalnością gospodarczą prowadzoną przez Sanatorium.

O prowadzeniu działalności gospodarczej przez Sanatorium świadczą $\$ 20^{24}$ oraz $₫ 22^{25}$ statutu. Potwierdzeniem, że podmiot ten prowadzi działalność gospodarczą jest punkt II regulaminu organizacyjnego Sanatorium (z 28 lutego

23 W opracowaniu przyjęto, że: administracja rządowa to podmioty, które podlegają kierownictwu Rady Ministrów w rozumieniu art. 146 ust. 3 Konstytucji (należy przez to rozumieć ich zależność osobową lub zależność stużbowa względem Rady Ministrów) oraz nie maja osobowości prawnej, „Zeszyty Prawnicze” 2011, nr 3(31).

$24 \$ 20.1$. Sanatorium jest utrzymywane ze środków finansowych pochodzacych $z$ realizacji umów o udzielanie świadczeń zdrowotnych zawieranych $z$ :

1) publicznymi i niepublicznymi dysponentami środków finansowych na ochronę zdrowia;

2) osobami fizycznymi.

2. Sanatorium może uzyskiwać środki finansowe zgodnie $z$ art. 55 ustawy $z$ dnia 15 kwietnia 2011 r. o działalności leczniczej.

Przepis art. 55 ust. 1 pkt 2 daje jednoznaczną wskazówkę co do tego, że sp zoz może także prowadzić inną działalność niż tylko udzielanie świadczeń zdrowotnych.

25 \$22. Sanatorium prowadzi wydzielona działalność inna niż działalność lecznicza $w$ zakresie:

1) oddawania w najem lub dzierżawę aktywów trwałych, zbędnych na cele działalności statutowej Sanatorium;

2) działalności hotelowej i rekreacyjnej;

3) sprzedaży positków;

4) prowadzenia parkingu. 
2019 r.), w którym stwierdzono: Wykonywanie działalności gospodarczej innej niż działalność lecznicza, pod warunkiem, że działalność ta nie jest uciążliwa dla pacjenta lub przebiegu leczenia (postanowienie to nawiązuje do art. 13 ustawy o działalności leczniczej ${ }^{26}$ ).

Ponadto w regulaminie mowa o: „pobieraniu opłat za usługi komercyjne”, a także o „sporządzaniu ofert leczniczych oraz komercyjnych, kalkulacji cen usług hotelarsko-leczniczych” oraz o „pozyskiwaniu nowych klientów”.

W związku z tym, że Sanatorium jako państwowa osoba prawna prowadzi działalność gospodarczą, wykorzystując przy tym mienie państwowe (art. $44^{1} \$ 1$ k.c.), w rozważanym stanie faktycznym znajdzie zastosowanie ograniczenie $\mathrm{z}$ art. 34 ust. 1 ustawy o wykonywaniu mandatu posła i senatora. Zgodnie $\mathrm{z}$ tym przepisem posłowie nie mogą m.in. zarządzać działalnością gospodarczą z wykorzystaniem mienia państwowego lub komunalnego.

$\mathrm{Na}$ możliwość stosowania art. 34 ust. 1 u.w.m.p.s. w przypadku pełnienia przez posła funkcji kierownika sp zoz zwrócono uwage w dotychczasowych opiniach Biura Analiz Sejmowych ${ }^{27}$. W opinii prawnej przygotowanej dla Komisji Regulaminowej i Spraw Poselskich ${ }^{28}$ stwierdzono: W ustawie o działalności leczniczej ustawodawca przesadził, że samodzielne publiczne zakłady opieki zdrowotnej nie maja statusu przedsiębiorców, nie rozstrzygną jednak, czy podmioty lecznicze prowadza działalność gospodarczą.

W wyroku z dnia 21 listopada 2014 r. [sygn. akt II OSK 2769/14 - dopisek I.G.-R.], Naczelny Sąd Administracyjny (dalej: NSA) przyjąt, że zakwalifikowanie przez ustawodawce $w$ art. 2 ust. 1 pkt 4 ustawy o działalności leczniczej samodzielnych publicznych zakładów opieki zdrowotnej do kategorii podmiotów leczniczych nieprowadzacych działalności gospodarczej wyklucza „możliwość zaliczenia podmiotu leczniczego, działajacego $w$ formie samodzielnego publicznego zakładu opieki zdrowotnej, do kategorii przedsiębiorców w rozumieniu przepisów ustawy o swobodzie działalności gospodarczej". W wyroku z dnia 22 lipca 2014 r. [sygn. akt II UK 192/13 - dopisek I.G.-R.] Sąd Najwyższy (dalej: SN) uznał, że ze wzglę-

26 Art. 13. W miejscu udzielania świadczeń zdrowotnych:

1) nie moga być świadczone usługi pogrzebowe oraz prowadzona ich reklama;

2) może być wykonywana działalność inna niż działalność lecznicza, pod warunkiem, że nie jest uciążliwa:

a) dla pacjenta lub przebiegu leczenia,

b) dla przebiegu leczenia - w przypadku jednostki wojskowej.

27 Tak: M. Szydło, Dopuszczalność łączenia mandatu posła ze stanowiskiem kierownika (dyrektora) samodzielnego publicznego zakładu opieki zdrowotnej [w:] Status posła w opiniach Biura Analiz Sejmowych (2007-2015), t. II, cz. 2, red. I. Galińska-Rączy, Warszawa 2015, s. 139-144.

28 P. Sobolewski, Opinia prawna w sprawie dopuszczalności łączenia przez posła MZ mandatu posła z pełnieniem funkcji dyrektora Śląskiego Centrum Chorób Serca, BAS-WAL 396/15, niepubl. 
du na brzmienie art. 2 ust. 1 pkt 4 ustawy o działalności leczniczej, samodzielne publiczne zakłady opieki zdrowotnej nie mają statusu przedsiębiorców.

$W$ przywołanych wyrokach NSA i SN trafnie stwierdzity, że brzmienie art. 2 ust. 1 pkt 4 ustawy o działalności leczniczej rozstrzyga, że samodzielne zakłady opieki zdrowotnej nie maja statusu przedsiębiorców, dlatego nie znajduja do nich zastosowania przepisy adresowane do przedsiębiorców np. art. 10 ustawy o swobodzie działalności gospodarczej. Należy jednak podkreślić, że pojęcia przedsiębiorcy i podmiotu prowadzącego działalność nie sa pojęciami tożsamymi. Pojęcie działalności gospodarczej zdefiniowane jest w ustawie z dnia 2 lipca 2004 r. o swobodzie działalności gospodarczej [t.j. Dz.U. 2015, poz. 584, ze zm. - dopisek I.G.-R.]. Według wskazanego artykułu działalnościa gospodarcza jest zarobkowa działalność wytwórcza, budowlana, handlowa, usługowa oraz poszukiwanie, rozpoznawanie $i$ wydobywanie kopalin ze złóż, a także działalność zawodowa, wykonywana $w$ sposób zorganizowany i ciagty. Przedsiębiorcami, w rozumieniu art. 4 ust. 1 ustawy o swobodzie działalności gospodarczej, moga być osoby fizyczne, osoby prawne i jednostki organizacyjne niebędace osobami prawnymi, którym odrębna ustawa przyznaje zdolność prawna - wykonujące we własnym imieniu działalność gospodarcza. Według art. 4 ust. 2 ustawy o swobodzie działalności gospodarczej za przedsiębiorców uznaje się także wspólników spółki cywilnej w zakresie wykonywanej przez nich działalności gospodarczej. Gdyby pojęcia „przedsiębiorcy” i "podmiotu prowadzacego działalność gospodarcza” stanowity synonimy posługiwanie się przez ustawodawcę dwoma różnymi terminami w jednym akcie prawnym byłoby nieracjonalne. W piśmiennictwie od dawna trafnie zwraca sie uwage, że rozstrzygnięcie przez ustawodawcę wprost $w$ przepisie, że określony podmiot nie jest przedsiębiorca nie oznacza, że podmiot ten nie prowadzi działalności gospodarczej ${ }^{29}$.

2. Należy przyjmować, że z uwagi na art. 2 ust. 1 pkt 4 ustawy o działalności leczniczej oraz powołaną interpretację tego przepisu przez NSA (wedle której samodzielne zakłady opieki zdrowotnej nie mają statusu przedsiębiorców) ${ }^{30}$, do omawianego stanu faktycznego nie znajdzie zastosowania art. 34 ust. 2 u.w.m.p.s.

3. W analizowanym przypadku możliwe jest skorzystanie przez posła $z$ urlopu bezpłatnego na podstawie art. 29 u.w.m.p.s. Urlop „poselski”, tak jak urlop bezpłatny ( $\mathrm{z}$ art. 174 Kodeksu pracy), jest przerwą w wykonywaniu pracy, w trakcie której pracownik nie wykonuje żadnych czynności i działań związanych z zakresem jego obowiązków pracowniczych. Nie wykonując swoich obowiązków pracowniczych, poseł nie będzie mógł być uznany za osobę „zarządzającą” działalnością gospodarczą w rozumieniu art. 34 ust. 1. Należy przy tym zastrzec, że

29 M. Szydło, Osoby wykonujące wolne zawody prawnicze jako przedsiębiorcy, „Przegląd Sejmowy" 2004, nr 2, s. 22.

30 Patrz również glosa G. Glanowskiego do wyroku SN z 22 lipca 2014 r. sygn. akt III UK 192/13 (PUG 2015). 
jeżeli poseł w okresie korzystania z urlopu bezpłatnego nie przerwałby świadczenia swojej pracy u danego pracodawcy i nadal de facto wykonywał tam czynności dające się scharakteryzować jako „zarządzanie” działalnością gospodarczą w rozumieniu art. 34 ust. 1 u.w.m.p.s., to wówczas, mimo formalnego trwania urlopu bezpłatnego, aktywność posła musiałaby być oceniana zgodnie z jej materialną treścią (i istotą), wywołując ryzyko naruszenia zakazu z art. 34 ust. 1 ustawy ${ }^{31}$.

\section{Podsumowanie}

1. Przedstawiona analiza podstaw prawnych utworzenia i funkcjonowania Sanatorium MSWiA (a zwłaszcza aspekt zależności od ministra właściwego ds. wewnętrznych) wskazuje, że podmiot ten można zaliczać do tzw. administracji świadczącej podlegającej kierownictwu Rady Ministrów, ale jednocześnie placówka ta, posiadając osobowość prawną, nie spełnia jednego z kryteriów określonych w Zasadach oceny sytuacji prawnej posła w związku z niepołaczalnościa jego mandatu" ${ }^{\prime 2}$ umożliwiających stosowanie zakazu z art. 103 ust. 1 Konstytucji.

W związku z tym, kierując się powyższymi Zasadami, należy uznać, że pozostawanie dyrektorem SP ZOZ Sanatorium Uzdrowiskowe MSWiA w nie jest zatrudnieniem $\mathrm{w}$ administracji rządowej w rozumieniu art. 103 ust. 1 ustawy zasadniczej. Poseł pełniąc tę funkcję, nie pozostaje w niepołączalności bezwzględnej (czyli nie znajduje wobec niego zastosowania art. $247 \$ 1$ pkt 5 Kodeksu wyborczego $\left.{ }^{33}\right)$.

31 M. Szydło, Urlop bezpłatny jako okoliczność przerywająca „zarządzanie działalnościa gospodarcza" w rozumieniu art. 34 ust. 1 ustawy o wykonywaniu mandatu posła i senatora[w:] Status posła w opiniach Biura Analiz Sejmowych (2007-2015), t. II, cz. 2, red. I. Galińska-Rączy, Warszawa 2015, s. 114 i n.

32 Zasady te zostały powtórzone przez Z. Cieślika w artykule Prawne ograniczenia publicznej, zawodowej i gospodarczej działalności posłów opublikowanym w zbiorze Seminarium dla nowo wybranych posłów IX kadencji, Wydawnictwo Sejmowe, Warszawa 2019.

33 Zgodnie $\mathrm{z}$ art. $247 \$ 1$ pkt 5 Kodeksu wyborczego wygaśnięcie mandatu posła następuje w przypadku zajmowania w dniu wyborów stanowiska lub funkcji, których stosownie do przepisów Konstytucji Rzeczypospolitej Polskiej albo ustaw nie można łączyć z mandatem posła.

Art. $247 \$ 3$ Kodeksu wyborczego stanowi, że wygaśnięcie mandatu posła zajmującego w dniu wyborów stanowisko lub funkcję, o których mowa w $\$ 1$ pkt 5 , następuje, jeżeli nie złoży on Marszałkowi Sejmu, w terminie 14 dni od dnia ogłoszenia przez Państwową Komisję Wyborczą w Dzienniku Ustaw Rzeczypospolitej Polskiej wyników wyborów do Sejmu, oświadczenia o złożeniu rezygnacji z zajmowanego stanowiska lub pełnionej funkcji. 
2. W rozważanym stanie faktycznym znajdzie jednakże zastosowanie zakaz wynikający z art. 34 ust. 1 u.w.m.p.s. (zakaz zarządzania działalnością gospodarczą z wykorzystaniem mienia państwowego), ponieważ SP ZOZ Sanatorium Uzdrowiskowe MSWiA w prowadzi działalność gospodarczą z wykorzystaniem mienia państwowego. Dla uniknięcia konsekwencji związanych $\mathrm{z}$ naruszeniem materialnej niepołączalności mandatu poselskiego wynikającej z art. 34 ust. 1 ustawy o wykonywaniu mandatu posła i senatora wystarczający będzie urlop bezpłatny. W rozważanym stanie faktycznym nie znajdzie zastosowania art. 34 ust. 2 tej ustawy (wymagający rezygnacji z funkcji).

\section{Bibliografia}

Cieślik Z., Prawne ograniczenia publicznej, zawodowej i gospodarczej działalności posłów [w:] Seminarium dla nowo wybranych posłów IX kadencji, Warszawa 2019.

Czarnik Z., Posłuszny J. [w:] System prawa administracyjnego, t. 6, Podmioty administrujace, red. R. Hauser, Warszawa 2011.

Dudek D. [w:] Konstytucja RP, t. II, Komentarz. Art. 87-243, red. M. Safjan, L. Bosek, Warszawa 2016.

Galińska-Rączy I., Czy podjęcie pracy na stanowisku dyrektora ośrodka kultury (samorzadowej instytucji kultury) nie będzie kolidować z petnieniem mandatu posła [w] Status posła w opiniach Biura Analiz Sejmowych (2007-2015), t. II, cz. 2, red. I. Galińska-Rączy, Warszawa 2015.

Jagielski J., Łączenie mandatu posła $z$ wykonywaniem pracy nauczyciela w samorządowej szkole podstawowej [w] Status posła w opiniach Biura Analiz Sejmowych (2007-2015), t. II, cz. 2, red. I. Galińska-Rączy, Warszawa 2015.

Jagielski J., Problem zaliczania Państwowego Gospodarstwa Leśnego „Lasy Państwowe” do kategorii „administracja rządowa” [w:] Status posła, cz. II, red. I. Galińska-Rączy, Warszawa 2007.

Lipowicz I. [w:] Prawo administracyjne, red. Z. Niewiadomski, Warszawa 2011.

Michalska-Badziak R., Podmioty administrujace [w:] Prawo administracyjne, pojęcia, instytucje, zasady w teorii i orzecznictwie, red. M. Stahl, Warszawa 2009.

Niewiadomski Z. [w:] Prawo administracyjne, red. Z. Niewiadomski, Warszawa 2011.

Radziewicz P., Decentralizacja jako pojęcie prawne, „Kwartalnik Prawa Publicznego” 2005, nr 1-2.

Stahl M. [w:] System prawa administracyjnego, t. 6, Podmioty administrujace, red. R. Hauser, Warszawa 2011.

Stahl M., Pojęcie administracji, jej cechy i funkcje [w:] Prawo administracyjne, pojęcia, instytucje, zasady w teorii i orzecznictwie, red. M. Stahl, Warszawa 2009.

Szydło M., Dopuszczalność łączenia mandatu posła ze stanowiskiem kierownika (dyrektora) samodzielnego publicznego zakładu opieki zdrowotnej [w:] Status posła w opiniach Biura Analiz Sejmowych (2007-2015), t. II, cz. 2, red. I. Galińska-Rączy, Warszawa 2015. 
Szydło M., Osoby wykonujące wolne zawody prawnicze jako przedsiębiorcy, „Przegląd Sejmowy" 2004, nr 2.

Szydło M., Urlop bezpłatny jako okoliczność przerywająca „zarządzanie działalnościa gospodarcza" w rozumieniu art. 34 ust. 1 ustawy o wykonywaniu mandatu posła i senatora[w:] Status posła w opiniach Biura Analiz Sejmowych (2007-2015), t. II, cz. 2, red. I. Galińska-Rączy, Warszawa 2015.

Szydło M., Zakaz łączenia mandatu parlamentarnego. Studium prawne, Warszawa-Poznań 2012.

Wiktorowska A. [w:] Prawo administracyjne, red. M. Wierzbowski, Warszawa 2011. 